\title{
Understanding Political Psychology and Its Importance to the Malaysian Politics
}

\author{
Khairul Azmi Mohamad ${ }^{1}$, Nooraini Othman ${ }^{1} \&$ Mazlan Ali $^{1}$ \\ ${ }^{1}$ Perdana Centre, Razak Faculty of Technology \& Informatics, Universiti Teknologi Malaysia, Malaysia \\ Correspondence: Nooraini Othman, Perdana Centre, Razak Faculty of Technology \& Informatics, Universiti \\ Teknologi Malaysia, Jalan Sultan Yahya, 54100 Kuala Lumpur, Malaysia. Tel: 60-3-2180-5157. E-mail: p- \\ noraini@utm.my
}

Received: April 26, 2020

doi:10.5539/jpl.v13n3p74
Accepted: July 27, $2020 \quad$ Online Published: August 17, 2020

URL: https://doi.org/10.5539/jpl.v13n3p74

\begin{abstract}
This paper intends to describe political psychology and the importance of the subject matter to the Malaysian politics. Political studies in Malaysia are largely based on political science, political sociology and socio-political analysis. It is a high time that political environment and issues in Malaysia to be looked upon from a psychological perspective. It is important because the discipline will allow the understanding of why political leaders think and behave in a certain manner. It will also allow the appreciation of voters' behaviour. These perspectives will enrich our ability to understand politics from different roots. In the context of Malaysia, studying political psychology will help to enhance the understanding of many variables related to the practice of politics in this country. The interactions between politics and psychology particularly the impact of psychology to politics would be an interesting study. As far as Malaysia is concerned, a deeper understanding on political psychology will help leaders to appreciate the nerves and needs of the people and they should put every effort to fulfil their aspirations. Political psychology should help to unfold the minds of the political actors as well as the voters.
\end{abstract}

Keywords: political psychology, Malaysian politics, political leadership, political behaviour

\section{Introduction}

Political psychology is regarded as a young field of studies in Malaysia. Students of the higher learning institutions only recently came to know and introduced to this discipline. Not many research specifically tackled issues of politics in Malaysia from the perspective of political psychology. Certainly, research and writings in this area would need to be enhanced to clearly reflect the strong presence of political psychology in Malaysia.

Political psychology gained prominence in the West. Theories and concepts are quite well developed. Empirical studies are done encompassing many perspectives in politics. Malaysia will need the same approach. The study has to be developed in order to understand contextually the Malaysian politics from this angle. This paper serves as humble attempt towards that direction.

\section{Methodology}

This paper came as a result of thematic literature review. The historical context as well as the more recent literature defining and conceptualising political psychology elucidate the subject of this work. The linkage between politics and psychology is equally established. It reflects the relevance of human behaviour to various political contexts. It further explicates polical psychology as a systematic field of study. Some of the areas of studies within the framework of political psychology are also clarified. The importance of political psychology to the analysis of politics in Malaysia is explained by way of analysing some of the relevant literature. A psychological analysis to politics is hoped to give a fresh perspective to political studies. This work highlights some of the important areas where Malaysians in particular is hoped to build interest on the subject matters.

\section{Overview of Political Psychology Concept}

The American Political Science Review in the year 1924 reported the Round table 1: Psychology and Political Science. The report was written by non-other than Charles Merriam himself. It was a summary of the Proceedings of the Round table on Psychology and Politics.

The first meeting was devoted to a general discussion and definition of the problem of the round 
table, namely the possibility of more intimate relationship between the study of politics and the study of psychology. Attention was first directed to the earlier development of psychology in the thinking of the classic political theorists and then to later reasons for interest in the psychological basis of political action (Merriam, 1924).

In the report, it was stated that the motivation for such closer study of the psychological bearings of politics was the desire for a deeper understanding of political behaviour as found in the surveys and analysis of political activities as well as developments of mental tests from which broad social and political implications have been drawn. It was concluded that the chief value of this round table was the opportunity to conduct scientific studies of the political side of human nature. It was believed that an advanced scientific study of traits of human nature underlying political actions, and of the processes that in reality constitute government.

The focus of political psychology can be seen as serving the interest of humanistic study as it relates to politics. It reflects on human behaviour relevant to various political contexts.

The systematic study of political psychology has been developing for almost 50 years, and it is now a well-established sub-field of enquiry in the North American academy and an increasingly recognised field of research in Europe and in the rest of the world. The intellectual roots of political psychology are both ancient and European, and the core theories, methods and studies in political psychology that have informed the development of the sub-field in North America have their origins in centuries of European scholarship. Many of the questions occupying political psychologists today thus originate in political philosophy and its commitment to theorise, critique and diagnose the norms and practices of political action across time and space. In this respect, political psychology, like political philosophy, has to do with the various symbols and categories that we use to organise our lives and through which we tend to make sense of the world. Similar to political psychology, political philosophy has always been concerned to address social problems and puzzles that have emerged throughout history and in specific contexts. It lies at the humanities end of political science, and is concerned with human behaviour in and across various political and cultural contexts. Hence, both political philosophy and political psychology share an interest in the humanistic study of politics. (Nesbitt-Larking et all, 2014)

Political psychology is also responding to the most current developments and events politically relevant taking place in the world. It is not a rigid discipline where only a specific issue falls under the purview of the discipline. It is dynamic in nature.

Political psychology has much been stimulated by the urgent political problems of the day, especially those with actually or potentially devastating human consequences (Sears, 1987).

Political psychology as a field must attempt to deal with the consequences of an increasingly borderless world in which identities are fluid, transformed, hybrid, or in search of secure identities. Such an orientation is, for us, highly suited to the tasks of developing truly global traditions and centres of research in political psychology throughout the world, notably the postcolonial world and the global south, while retaining an openness to whatever the discipline might become (NesbittLarking and Kinnvall, 2012).

As an identifiable specialty, political psychology has drawn together a variety of intellectual strands previously located solely in the traditional social science discipline (Sears, 1987). Political psychology is inherently interdisciplinary, engaging scholars from several disciplines who draw on diverse theoretical frameworks to inform their research. As a result, political psychology is a richly pluralistic field (McGraw, 2000).

As a very broad definition, it is safe to say that the field of political psychology is concerned with explaining political phenomena from a psychological perspective. This means that political psychologists study political decision making, political action, and political attitudes through the perspective of unobservable psychological processes unfolding in the minds of political actors. In doing so, scholars typically explain a political phenomenon with established psychological concepts. For most political psychologists, contributing to understanding the political context is the primary goal of their endeavor (Krosnick, 2017).

This dominance of political scientists might explain why political psychology—very much unlike other fields in psychology - seems to be predominantly not concerned with identifying pan-contextual principles of how the human mind works. Even though psychological theories are typically applied to understand political phenomena, this research rarely has attempted to advance our understanding of these psychological theories. Instead, much political psychological research is based on a genuine interest in understanding the political context. 
For instance, many scholars in the field have applied psychological theories about human cognition and behaviour to political decision-making or voting behaviour. This approach has yielded useful insights for political science, but the explicitly stated benefit for psychology — and for understanding of the human mind in general—has been more limited. Research in political psychology may quite easily serve both purposes if researchers begin their projects by aiming to produce findings with implications of two sorts: (1) implications for understanding of politics and (2) implications for basic psychological theory. Research that focuses only on the first outcome may be better described as psychological political science but not as political psychology (Krosnick, 2002). In fact, the term "political psychology" implies that it is a form of psychology. As such, the field can contribute to the larger psychological endeavor of studying behavioural and mental processes to discover general laws if researchers choose to do so from the outset of their efforts and take the time to explain those implications in publications.

Conducting political psychology in the hope of advancing basic psychological theory is especially likely to help psychology, because more often than not, political psychologists step out of the laboratory and conduct their research on the real world. This is valuable partly because it maximizes the external validity of research findings. But a mix of lab and field studies can maximize both internal and external validity, and studies of the real world often enrich basic psychological work by pointing to processes, mediators, and moderators that would not necessarily find their way into theorizing about impoverished, constructed context-free lab settings. Experimental research might be best viewed as suggestive about how people make decisions and behave in similar situations in the real world.

But a mix of lab and field studies can maximize both internal and external validity, and studies of the real world often enrich basic psychological work by pointing to processes, mediators, and moderators that would not necessarily find their way into theorizing about impoverished, constructed context-free lab settings. Experimental research might be best viewed as suggestive about how people make decisions and behave in similar situations in the real world (Krosnick, 2017).

Some would look at political psychology from the interactional perspective.

Political psychology can be defined most simply as the study of the interaction between politics and psychology, particularly the impact of psychology on politics....The intersecting area between economics and politics is called "political economy," between sociology and politics "political sociology," and so on. The intersection of mathematics and politics has developed its own specialized terminology — rational choice, formal theory or game theory—but it is essentially "mathematical politics" (Houghton, 2009).

Attention must be given to Charles Merriam's Roundtable report where the members present then recorded their optimism that a new field that would be focusing on the human nature and human behaviour of politics could contribute to the understanding of politics - both the actions and the actors. Their wisdom and vision have today witnessed the progress and maturity of political psychology as a distinct discipline of study with a more sophisticated worldview.

A country like Malaysia must put every effort to contextually understand and develop political psychology in its broadest sense with a view to materialise a better politics in the country. A better politics with better leaders will give rise to a better government that would better contribute to its people and the overall nation building.

\section{The Importance of Political Psychology in Malaysia}

Political psychology as a field must attempt to deal with the consequences of an increasingly borderless world in which identities are fluid, transformed, hybrid, or in search of secure identities. Such an orientation is, for us, highly suited to the tasks of developing truly global traditions and centres of research in political psychology throughout the world, notably the postcolonial world and the global south, while retaining openness to whatever the discipline might become (Nesbitt-Larking and Kinnvall, 2012).

The study of Political Psychology in Relation to Political Leadership, Trust and Voters' Behaviour will bring fresh elements to the study of politics in Malaysia. Not only it is from the discipline of psychology, but also from the scientifically new designed instrument.

As per Lavine (2010), the realm of Political psychology studies could bring the following effects:

a) An awareness among psychologists of the creative application of psychological theory within the domain of politics;

b) The usefulness of politics as a vehicle for developing and refining psychological theory; and

c) A deeper appreciation among political scientists of the psychological roots of political behaviour. 
Political psychology is essentially a field of study that synergises two distinct disciplines, namely politics and psychology. The marriage of the two disciplines reflects its paramount importance and the proximity as well as the relationship of the two towards one another.

In politics, normally people speak about numbers - the winning or the losing numbers, leaders and followers, voted in or voted out, and people and power. Psychology on the other hand speaks about mind and behaviour. The combination of politics and psychology will explain among others why leaders act in a certain manner, what is the leadership personality that is liked by the people, the reasons why people vote a particular individual or party, the dynamics and changes in voting behaviour according to time, locality and circumstances, and finding means of winning the hearts and minds of the voters.

Thus, political psychology is an important aspect to be studied in the context of Malaysia. Many studies have been done in the context of political science, political development, political history and political sociology but not specifically in the realm of political psychology. The current reality in the Malaysian politics deserves analysis and treatment from the perspective of political psychology.

Much has been said about voters' behaviour that would lead a particular political party to be in power. Studies are made in the context of political psychology by giving a deep focus into how voters vote and why they vote in that manner. In addition to that, political psychology will allow the focus of study on the leadership mind and behaviour. Leaders thinking and actions would naturally form a catalyst, giving a strong enough reason for the leaders and the party to be voted in.

In essence, leaders and their works will form the reason for the voters' decision either to allow them to be in power or to continue to be in power or alternatively enough is enough, they should retire. Generally, the public or the citizens do not actively involve in politics. It is the politicians who crafted their agenda and launch their campaign to lure voters to come to their side and vote them or their party.

Political leadership attracts support and vote. It is like the first impression people have towards a person and perhaps collectively as a party. It relates to matters that voters would want to see in a leader. A weak leader does not deserve a vote. A corrupt leader should not stand re-elected. People generally want to have a leader who is honest, full with integrity, able to sustain challenges, possess high skill of diplomacy, charismatic, far sighted, visionary, intelligent, passionate in works, reliable, disciplined and courageous. In essence, it relates to leadership personality, behaviour and character.

Similarly in the context of a party, when the party provides what it takes to lead a country, naturally the party would win the support of the people and gets voted in. People would support the party that reflect the leadership integrity, honest and loyal to the struggle, putting people above all, be the one that serves the nation and not prone to corruption.

Political trust is extremely important. It decides if the people would want to vote a particular political party to lead a particular country or constituency. It is therefore important for the leadership of a party to ensure that his party merits the vote of the people because the people trust his party to be in power. It is indeed a big task.

To gain political trust by the people, party's image is a critical factor. What is your image in the eyes of the people? In essence, when your voters look at you or your party, what do they see or rather how do they see you? 'You' here refers to the party as well as the leaders of the party. To a certain extent it refers to the members of the party.

What are the matters that the people look or judge in order to decide which party to vote? Are you reliable? If in the last election the people voted you in, will they do the same in the coming election or they see no merit anymore in you? A chain of questions would follow, one after the other. Answers to these matters would be some of the most important deciding factors for a particular candidate or party to win the election.

Trustworthiness and reliability would normally result from good policy and programs that the leader or party who lead the government initiate or implement. These programs benefited the people and the country. The people felt that in the election, the leadership and its party deserve to be given the opportunity to lead the country because they are trustworthy and the country will be in their good hands. Trustworthiness is vote worthiness.

Contextually, voters' behaviour refers to the Malaysian voter's selection in terms of which party or its candidate chosen to represent the people in a given constituency. The basis of their choice will be political leadership and political trust. Their votes will ultimately decide who rules the state and federal governments.

\section{Conclusion}

As the interdisciplinary study of the psychological aspects of human political behaviour, political psychology explores the border that runs between the intellectual nations of political science and psychology. In doing so it 
encompasses such topics as electoral politics, the shaping of public policy, leadership, elite decision-making, intergroup relations, personality and political ideology, political violence, and conflict resolution (Suedfeld and Jhangiani, 2009).

Political psychology addresses the political behaviours of the elite as well as the masses, in both cases exploring the reciprocal determinism between political behaviour, individual psychology, and the political context. Political psychology is also the application of psychological research methods, theory, and data to politics. Political scientists apply psychology to their research and psychologists apply their research in a political context (Jhangiani and Suedfeld, 2019).

In the context of Malaysia, studying political psychology will help to enhance the understanding of the many variable related to the practise of politics in this country. What leaders think, why they behave in a certain manner and what motivates voters to vote are some of the perspectives that merit exploration.

Ultimately, it is important to analyse the relevant variables as it relate to political leadership, political trust and their relationship to the voters' behaviour. If political parties in Malaysia embody these aspects of the analysis in their party works, naturally they would understand better the feelings and aspirations of the voters. By these appreciations, political leaders will know how to become a better politician. It is only proper for politicians to understand the needs of the grounds. These days, a thin-air politician does not deserve any trust by the people and does not merit to be allocated any seat.

\section{Acknowledgments}

Appreciation goes to the the Ministry of Education Malaysia under the sponsorship of Fundamental Research Grant Scheme (FRGS - 05F018).

\section{References}

Houghton, D. P. (2009). Political Psychology: Situations, Individuals, and Cases. Routledge: New York. https://doi.org/10.4324/9780203889114

Krosnick, J. A. (2002). Is political psychology sufficiently psychological? Distinguishing political psychology from psychological political science. In Kuklinski (Ed.), Thinking about Political Psychology. New York: Cambridge University Press. https://doi.org/10.1017/CBO9780511510632.007

Krosnick, J. A., Stark, T. H., \& Chiang, I.-C. A. (2017). The Two Core Goals of Political Psychology. In J. A. Krosnick, T. H. Stark, \& I.-C. A. Chiang (Eds.), Political Psychology: New Explorations. Routledge, New York and London. https://doi.org/10.4324/9781315445687

Krosnick, J. A., Visser, P. S., \& Harder, J. (2010). The Psychological Underpinnings of Political Behaviour. Handbook of Social Psychology, Wiley Online Library. https://doi.org/10.1002/9780470561119.socpsy002034

Lavine, H. (2010). A Sketch of Political Psychology, Political Psychology. Sage Publications Ltd., USA.

McGraw, K. M. (2000). Contributions of the Cognitive Approach to Political Psychology. Political Psychology, 21(4). https://doi.org/10.1111/0162-895X.00217

Merriam, C. E. (1924). Roundtable 1: Psychology and Political Science. The American Political Science Review, 18(1), 122-125. https://doi.org/10.2307/1943702

Merriam, C. E. (1924). The Significance of Psychology for The Study of Politics. The American Political Science Review, XVIII(3). https://doi.org/10.2307/1944171

Nesbitt-Larking, P. (2013). Complexes and Cognitive Complexity: Canadian Contributions to Political Psychology. Canadian Journal of Political Science / Revue Canadienne de science politique, 36(4), 879-896. https://doi.org/10.1017/S0008423903778901

Nesbitt-Larking, P., \& Kinnvall, C. (2012). The Discursive Frames of Political Psychology. Political Psychology, 33(1), 45-59. https://doi.org/10.1111/j.1467-9221.2011.00862.x

Nesbitt-Larking, P., Kinnvall, C., Capelos, T., \& Dekker, H. (2014). Introduction: Origins, Developments and Current Trends. In P. Nesbitt-Larking, C. Kinnvall, T. Capelos., \& H. Dekker (Eds.), The Palgrave Handbook of Global Political Psychology. Palgrave Macmillan, United Kingdon and USA. https://doi.org/10.1007/9781-137-29118-9_1

Sears, D. O. (1987). Political Psychology. Ann. Rev. Psychol., 38, 229-255. https://doi.org/10.1146/annurev.ps.38.020187.001305 
Suedfeld, P., \& Jhangiani, R. (2009). Cognitive Management in an Enduring International Rivalry: The Case of India and Pakistan. Political Psychology, 30(6). https://doi.org/10.1111/j.1467-9221.2009.00736.x

\section{Copyrights}

Copyright for this article is retained by the author(s), with first publication rights granted to the journal.

This is an open-access article distributed under the terms and conditions of the Creative Commons Attribution license (http://creativecommons.org/licenses/by/4.0/). 